\title{
The Heart of South Vietnam
}

\author{
Saigon in the Sixties
}

During the rainy season in southern Vietnam, afternoon storms give way to breezy evenings that beckon people outdoors to enjoy a touch of cool in the thick tropical air. Friday, June 25, 1965, was one of those nights in Saigon. The riverfront across from Bach Dang Street and the Majestic Hotel, not far from the US Embassy, was alive with parents chasing children, young lovers strolling by the water, street merchants selling food and drink, and customers arriving for dinner at the My Canh riverboat restaurant. My Canh was packed that night, and Saigon businessmen dined on fresh seafood and drank French wine alongside American GIs and their Vietnamese girlfriends. Seated at a table with friends, trying to talk above the din of conversation, laughter, and silverware on dishes, a diner would not have noticed a bomb that was set to go off at $8: 15 \mathrm{pm}$. After it exploded, stunned patrons who were able to stumble down the gangway to get off the ship would not have noticed a second bomb attached to a bicycle that was leaning against a cigarette stand on the riverbank near the end of the gangway. It exploded shortly after the first bomb. Of the nearly fifty people killed by the two blasts, more than half were Vietnamese, mostly women and children. The bombing was not random; it was part of a broader National Liberation Front strategy to destabilize the political situation in Saigon. The city was a war zone, and the urban war was hot long before the Tet Offensive.

There were two currents of energy pulsating through Saigon when it was the capital of South Vietnam. One crackled and sparked from the friction between citizen political activism and the South Vietnamese government's measures to suppress dissent. The electricity generated a palpable buzz in a city that was one of the most dynamic in the world in 
the I960s and I970s. The other was a high-voltage throb of danger that reminded urbanites that Saigon was a city at war. The armies may have been fighting in the villages, but in a guerrilla war, attacks on civilian targets in cities left a psychological impact that could not be measured by a body count. Throughout the war years, the two currents often were

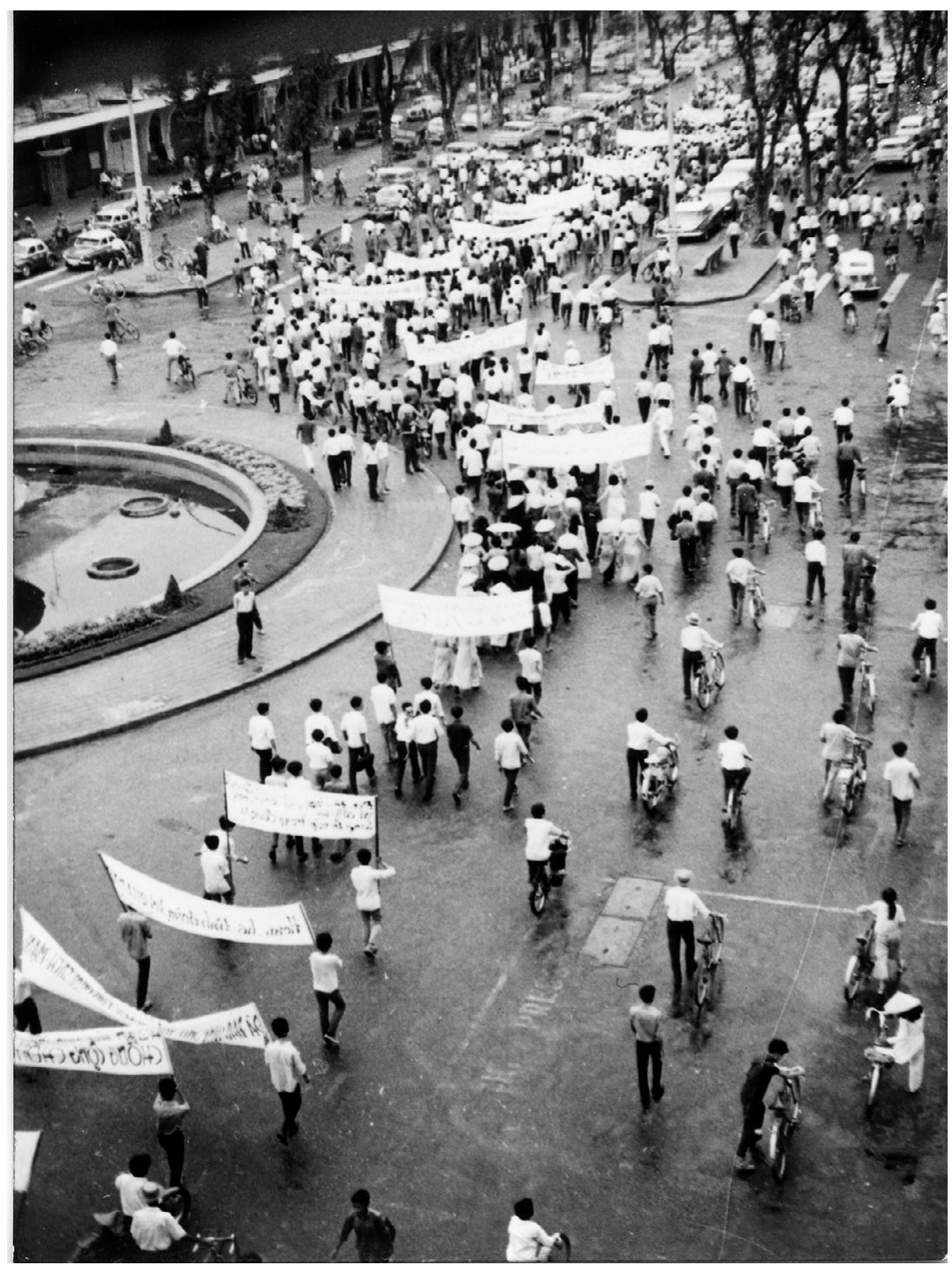

FIgURE I. I Organized demonstration against the Viet Cong, Saigon, I964. Earl R. Rhine Collection, The Vietnam Center and Archive, Texas Tech University 
inseparable. In some ways, South Vietnam was a nascent democracy where citizens grappled with multiple perspectives on Vietnam's postcolonial political identity as they attempted to establish a modern, republican political system. Yet government repression of known and suspected political opponents intersected with NLF determination to control, through violence if necessary, South Vietnam's capital city. The forces of political instability and NLF terrorism destabilized South Vietnam. Some days, Saigon residents went about their business spared of the brutality of rural combat. But then a bomb would go off in a movie theater, or a newspaper editor would fall victim to a drive-by assassination, and it would remind residents that their city was at war.

Through terrorism, the NLF aimed to instill fear in the citizenry and destabilize Saigon's political system, undermining efforts to establish a democratic society. The violence compounded the disorder in the capital city and other urban areas where students, intellectuals, and journalists protested the government's slow movement in enacting democratic political institutions and allowing citizens to elect a civilian government. Saigon officials responded to terrorist attacks by arresting and imprisoning political dissidents and assuming that anyone who spoke out against the government was a communist. The stifling of civil liberties in turn validated claims by the NLF and other anti-government groups that Saigon leadership was authoritarian - terrorism's mission accomplished.

\section{SAIGON'S POLITICAL REVOLVING DOOR}

The 1963 assassination of Ngo Dinh Diem left a political vacuum in Saigon that a coalition of generals worked to fill. After Diem's ouster, Duong Van Minh, a southern-born general, dissolved the National Assembly and formed the Military Revolutionary Council, a collection of military officers who sought to build up a base of political support that would give them an advantage in negotiations with the NLF. ${ }^{\mathrm{I}}$ At its inception, the new government enjoyed popular support from citizens happy to see the Diem regime come to an end. Public confidence in the government faltered, however, not long after Minh took power, as his lack of leadership skills became clear, and political infighting prevented the establishment of democratic institutions. ${ }^{2}$ Meanwhile, at the Vietnam

${ }^{1}$ Mark Atwood Lawrence, The Vietnam War: A Concise International History (New York: Oxford University Press, 2008), p. $8 \mathrm{I}$.

${ }^{2}$ William J. Duiker, Vietnam: Revolution in Transition (Boulder, CO: Westview Press, I995), p. 66. 
Workers Party Ninth Plenum in Hanoi in December 1963, delegates had approved a resolution authorizing the use of military force as the main way to unify Vietnam, and the NLF sought to take advantage of the political instability in Saigon. ${ }^{3}$ On January 29, 1964, General Nguyen Khanh overthrew Minh's government in a bloodless coup. At the end of 1964, People's Army Vietnam or North Vietnamese Army main force units began crossing the DMZ. ${ }^{4}$

Although Khanh had promised US advisors that he would wage a more effective war against the NLF, within just a few months of his taking power, Lyndon Johnson began to worry that the Khanh government was too weak to lead a stable state. ${ }^{5}$ Emboldened citizens demanded a civilian government, protesters clogged the streets of Saigon and Hue, and ARVN desertions increased through to the end of $1964 .^{6}$ Late 1964 saw the move toward establishing a civilian government and a new constitution, but subsequent clashes between generals and civilian politicians led to several additional coups and urban unrest. US Ambassador to South Vietnam Maxwell Taylor pushed the various parties in Saigon to get their affairs in order or risk loss of US aid and easy defeat by the NLF. A year after the assassination of Diem, Saigon was "a mess," as an anti-Khanh pamphlet put it."

Developments in South Vietnam were central on international radar screens, and in the early post-Diem years, conversations revolved around the issue of neutrality. In 1964, French President Charles De Gaulle proposed that Western nations work with China to establish a neutral political solution to the conflicts in Indochina as the only way to ensure peace. De Gaulle had broached the topic of a French-administered, neutral unification of the two Vietnams with John F. Kennedy in the summer of 1963 , a few months before the assassination of Ngo Dinh Diem, but Kennedy rejected the idea as long as the NLF existed in South Vietnam. Lyndon Johnson's response was similar: He was willing to consider such

3 Sophie Quinn-Judge, "The Search for a Third Force in Vietnam: From the Quiet American to the Paris Peace Agreement," Vietnam and the West: New Approaches, Wynn Wilcox, ed. (Ithaca, NY: Cornell University Press, 2010), I62-164. See also, Lawrence, The Vietnam War, p. 8I; South Vietnam, Volume I: U.S.-Communist Confrontation in Southeast Asia, I96I-65, p. I04.

${ }^{4}$ Duiker, Vietnam, pp. 66-69. ${ }_{5}^{5}$ Lawrence, The Vietnam War, pp. 84-85.

${ }^{6}$ Mark Philip Bradley, Vietnam at War (New York: Oxford University Press, 2009), p. Io8.

7 VNCH Phiếu Trình Thủ Tương, v/v hoạt động chống chánh-phủ, I-I965. Ho so so I 5406: vềcác hoạt động chống đối chính phủ VNCH, Việt Công tại Sài Gòn năm I965. Phông Phủ Thủ Tướng Chính Phủ Việt Nam Cộng Hòa Từ năm I954 đến năm I975, Trung Tâm Lưu Trữ Quốc Gia II (National Archives II, hereafter TTLTQG II), Ho Chi Minh City, Vietnam. 
a plan, but only if North Vietnam agreed to end the communist insurgency it directed in South Vietnam. Otherwise, any attempt at neutrality would facilitate a communist takeover of the country. ${ }^{8}$ Duong Van Minh had desired neutrality for South Vietnam, and Nguyen Khanh justified his ouster in Saigon by arguing that deposing Minh was required as leader of South Vietnam to counter the forces of neutralism. US Senator Mike Mansfield had promoted the cause of neutralism to Congress, but Ambassador Henry Cabot Lodge, who replaced Taylor in I965, asked De Gaulle to withdraw his proposal for the same reasons Kennedy and Johnson had dismissed it. "How can so-called 'neutralization' be attained if the aggressor is determined not to be neutralized, as is obviously the case as regards North Vietnam?" he wondered. ${ }^{9}$

Buddhist opposition remained a problem to the new Saigon government as it had been during the Diem era. In January 1964, politically active Buddhists formed the Unified Buddhist Church as a way to try and bring Buddhists together. Conflict among UBC members typically centered on the issue of neutralism. During the Cold War, some newly independent nations adopted a neutral stance on the United States-Soviet struggle to draw new allies into their respective orbits. The Non-Aligned Movement exemplified this position in its conference at Bandung in 1955 and in other efforts to assert independence from superpower meddling. As historian Fredrik Logevall has pointed out, in the South Vietnamese context, neutralism referred more to a general war weariness. ${ }^{\text {IO }}$ Peasants especially were interested in whatever approach would force both the Saigon government and the NLF to leave them alone. Britain's ambassador to South Vietnam wrote to London in I963: "The peasants do not want Communism, but if the Government cannot protect them they will support the Communists. Urban populations felt the war exhaustion, too, as American and French officials suspected when they assessed the excitement over Diem's assassination. Some Vietnamese hoped that the collapse of his regime meant that the war would soon end. ${ }^{\text {II }}$

${ }^{8}$ South Vietnam, Volume I: U.S.-Communist Confrontation in Southeast Asia, I961-65, Lester A. Sobel, ed. (New York: Facts on File, Inc., I973) 86, 97. See also, Lam Quang Thi, The Twenty-Five Year Century: A South Vietnamese General Remembers the Indochina War to the Fall of Saigon (Denton, TX: University of North Texas Press, 200I), p. I I2.

9 Quinn-Judge, Vietnam and the West, p. I62.

ro On the nonaligned movement, see Robert B. Rakove, Kennedy, Johnson, and the NonAligned World (New York: Cambridge University Press, 20I2).

${ }^{I}$ Fredrik Logevall, Choosing War: The Lost Chance for Peace and the Escalation of the War in Vietnam (Berkeley: University of California Press, I999), p. 89. 
Buddhist leaders were divided on the question of neutralism, but the concept gradually united Buddhists and student leaders who did not trust Nguyen Khanh. They worried that rumors of military officials plotting Khanh's overthrow would prove true, spinning the revolving door of the palace once again to seat another nonelected, noncivilian government. They supported a policy of neutralism that would force the United States to withdraw from South Vietnam and allow representatives of various political persuasions to negotiate an end to the war. Hanoi and NLF leaders also supported this approach, which made it all the more threatening to American advisers. ${ }^{\mathrm{I2}}$ Thich Tam Chau, leader of moderate Buddhists, advocated a pro-government, anti-neutral stance. Thich Tri Quang, leader of Vien Hoa Dao, the Institute for the Propagation of the Faith, which was the political arm of the UBC, wanted the South Vietnamese government and the NLF to figure out a settlement to end the war. Increasing US involvement in Vietnam and violence throughout the country strengthened ties between the Buddhists and other activist groups, especially students. ${ }^{\mathrm{I3}}$

August I964 was a particularly bloody month in Saigon. Protests against Nguyen Khanh's military government continued as part of a vicious cycle of citizen demonstrations, government crackdowns, rising citizen anger, and additional restrictions on democracy. Official proclamations authorizing police to move proactively against suspected security risks sometimes resulted in bloody attacks against groups that potentially were bases of support for the government. In late August 1964, officers shot and killed six Catholics who marched in front of the military's high command headquarters at Tan Son Nhut airport demanding representative government. Thousands of mourners turned out for the funeral procession several days later, and the government issued a statement acknowledging the "patriotism" of the slain demonstrators and admitting that the officers responsible had "lost their calm in crisis." Authorities offered 50,000 piasters to each family of the murdered protesters and promised to investigate the conduct of the officers involved in the incident. ${ }^{\mathrm{I}}$ At the same time, the Armed Forces High Command also issued a statement warning citizens that police would call in military reinforcements if crowds became unruly. Troops will have the authority to

${ }^{\mathrm{I} 2}$ Logevall, Choosing War, p. I20-I2I.

${ }^{13}$ Robert Topmiller, The Lotus Unleashed: The Buddhist Peace Movement in South Vietnam, I964-I966 (Lexington: University Press of Kentucky, 2002), p. 7.

${ }^{14}$ "Services for Six Killed," Saigon Daily News, Monday, Aug. 3 I, I964, p. 4. 
blockade government buildings and other official installations, and if protesters attempt to cross the barricades, security forces would be "obligated to open fire to make the national authority respected." ${ }^{5}$

Authorities justified their harsh responses to citizen protests as necessary to bring order as government officials struggled to both establish new democratic political institutions and fight a war against the NLF. Yet state violence against civilians, even just in the form of threats, presented an image to Vietnamese citizens and the world of another example of authoritarianism taking root in the decolonizing world. South Vietnam's authoritarianism in the name of democracy enforced the notion that newly independent populations had only the choices between authoritarianism and communism for their political structures. Despite citizen protests and a vibrant press, South Vietnam looked reactionary. In the midsixties, leaders gave international observers little reason to believe that they were committed to building a democratic nation.

State suppression of civil liberties increased with US escalation in April 1964. The clash between US ships and North Vietnamese PT boats in the Gulf of Tonkin and subsequent US bombing of targets in North Vietnam resulted in Khanh's declaration of a state of emergency in South Vietnam. ${ }^{16}$ Authorities imposed a curfew in Saigon and seized newspapers accused of printing anti-government articles. The Ministry of Interior issued a statement banning any object that could be construed as a weapon from public gatherings, and the ARVN High Command announced that troops would be deployed to aid police forces if police lose control of demonstrations. The stakes were high for civilians: Anyone caught with a weapon would be tried in a military court, and if troops were called in to assist police in riot control, they would be permitted to open fire on demonstrators "to make the national authority respected." ${ }^{17}$ In the fall of 1964, the Khanh regime established a civilian High National Council, which appointed Tran Van Huong, former mayor of Saigon, premier of South Vietnam. ${ }^{18}$

I5 "High Command Issues Anti-Riot Warning," Saigon Daily News, Monday, Aug. 3 I, I964, p. 2.

${ }^{16}$ South Vietnam, Volume I: U.S.-Communist Confrontation in Southeast Asia, I96I-65, p. IOI.

17 "High Command Issues Anti-Riot Warning," "City Hall: Military Trial Awaits Armed Marchers," "Ministry Warns against Carrying Weapons," Saigon Daily News, Aug. 3 I, I964, pp. 2-3.

${ }^{18}$ South Vietnam, Volume I: U.S.-Communist Confrontation in Southeast Asia, I961-65, Lester A. Sobel, ed. (New York: Facts on File, Inc., I973) I06-107. 
Though a civilian, Huong did not earn much support from politically active citizens, especially Vietnamese students. Huong increased draft calls, one of the main issues motivating student unrest, and demonstrations against the government continued, followed by arrests of protesters. Additional attempted coups removed Khanh from power for good in February 1965. That summer, a team of younger generals, led by Air Marshal Nguyen Cao Ky and Army General Nguyen Van Thieu, took control of the government and surprised Washington by bringing some stability to Saigon. ${ }^{\text {I9 }}$ In February 1966, Thieu and Ky met with Johnson and other Americans in Honolulu to discuss strategies for building a base of popular support. Johnson promised to increase aid to help South Vietnam's economy and social issues, and Thieu and Ky agreed to make concrete efforts toward establishing a representative civilian government. Thieu and Ky promised that they would call for elections to a constituent assembly within the year. Voters elected a II7-member constituent assembly, which then drafted a new constitution - one of the demands citizen activists had wanted since Diem's assassination. ${ }^{20}$ The government also established the processes for a nationwide presidential election. In September 1967, Thieu won the presidency with 35 percent of the vote, with $\mathrm{Ky}$ as his vice president. The second-place candidate, Truong Dinh Dzu, received 17 percent of the vote. ${ }^{2 I}$

\section{LIFE FOR AMERICANS AND VIETNAMESE IN SAIGON}

Saigon was a chameleon, able to be what observers and residents believed it to be, perhaps because it was so many things. Journalist Chin Koh Chong of the Pan-Asian Newspaper Alliance, saw a place that was oblivious to the war happening just beyond city limits. Its boulevards, shaded by tamarind trees, hosted busy outdoor cafes and shops that catered to local women of leisure, as well as foreigners, primarily American men, but in some cases their wives, too. Inside the crowded markets, shoppers bargaining for fruit, vegetables, and fish composed a noisy soundtrack that mixed with the near-constant rumbling of motorbikes and vehicles moving through the streets outside. ${ }^{22}$ Political coups occurred without troops, tanks, or bloodshed. While Saigon residents went about their business one Saturday in February 1965, a group of

${ }^{19}$ Duiker, Vietnam, p. $68 . \quad{ }^{20}$ Ibid. $\quad{ }^{21}$ Bradley, Vietnam at War, p. I Iо.

${ }^{22}$ Chin Kah Chong, "A Coup D'Etat Is a 'Curious Custom' in South Vietnam," Malayan Times, April I7, I965. 
generals deposed Nguyen Khanh. They announced the regime change over the radio and promised that they intended to assemble a civilian government. ${ }^{23}$ The illusion of being apart from the war made terrorist attacks even more jarring.

As Ann Laura Stoler has written, one way to trace power and power relations is to examine the "intimate" moments of daily life - instances when ordinary encounters among people define social hierarchies and categorize individuals for the sake of creating or maintaining power. ${ }^{24}$ On the streets, in public places, and in private moments, Americans and Vietnamese, civilian and military personnel, women and men, mingled in trysts that were fraught with, to borrow Stoler's phrase, the "tensions of empire." Stoler identifies "the colonial" as the "settlement, exploration, and dominance of separate 'others' that transforms social organization, cultural convention, and private life." ${ }^{25}$ In the neoimperial world of postI945 US foreign relations, the American presence in Vietnam was not designed for territorial acquisition, but to protect and extend political and economic power. To do so meant that Americans would occupy Vietnam, and even though the occupation was always considered temporary, its impacts on Saigon were lasting.

For some Americans living in Saigon, the city was a place of comfort and leisure, which made terrorist attacks all the more jarring - and effective. Marion Williams, a journalist and nurse who went to Vietnam in I967, wrote that there were two sides to the American war in Vietnam the "non-combat luxury war" and the "field hardship war." "The bitching war is hell for the front line internment along the DMZ and the Mekong Delta," she wrote, "while in Saigon, Cam Ranh Bay, and many other places, the luxury men live high. They have nice living quarters, maid service, enlisted men's clubs, cold beer, T-bone steaks, J\&B scotch, not to mention many other fine scotches and bourbons. Some even had automatic washers and dryers. Just like state-side living. If war could be like this for all men, it would become a pleasure to go to war." ${ }^{26}$ Some American men found in Saigon a bachelor's life of good food, good

${ }^{23}$ Allington Kennard, "The City of Quiet Coups," The Straits Times, Feb. 28, 1965.

${ }^{24}$ Ann Laura Stoler, "Intimidations of Empire: Predicaments of the Tactile and Unseen," in Haunted by Empire: Geographies of Intimacy in North American History, ed. Stoler (Durham, NC: Duke University Press, 2006).

25 Ibid., p. 32.

${ }^{26}$ Marion L. Williams, My Tour in Vietnam: A Burlesque Shocker (New York: Vantage Press, I970), p. 36. 
liquor, and a Vietnamese woman to keep their apartments tidy, and provide other services.

The black market for entertainment for foreigners in Saigon flourished thanks to men like William Crum. Crum was in the business of entertainment, running companies that distributed liquor, dry goods, and games such as slot machines. The son of an American Yangtze River pilot, Crum was born in Shanghai in I9I 5 and lived there until I935, when his family moved to California. The military fascinated him, and he tried to enlist in the Navy when the United States entered World War II, but muscular dystrophy kept him out of the service. By the time of the Korean War, though, Crum had figured out a way to get close to the military and almost feel a part of it. He pitched his business to post exchanges, officers' clubs, and enlisted men's clubs in hopes of getting distribution contracts for military installations. When the United States escalated the war in I965, Crum saw an opportunity to expand his business ventures. ${ }^{27}$

In bidding to win military contracts, Crum did more than submit proposals. He had skilled himself in the art of bribery. The practice almost caught up with him in Korea, where a sergeant in charge of the club system there was court-martialed for allegedly accepting bribes from Crum. Crum fled Korea in 1960 and made his way to Vietnam, where he found other military officers willing to accept his kickbacks. In late I965, the Army and the Air Force ran the post exchange (PX) system in Vietnam, and five American men - one military officer and four civilians - oversaw the operations there. As a I97I Senate inquiry into corruption in the club and PX systems stated, "when these men arrived in Vietnam, William Crum and his associates were ready to make their stay more comfortable." ${ }^{28}$

Upon arrival of Lieutenant Colonel John G. Goodlett Jr. and his civilian assistants Peter B. Mason, Richard Llewellyn, and Clarence Swafford in the fall of 1965 , Crum provided them accommodations in a villa in Saigon. The two-story home featured five bedrooms, a living room, dining room, three bathrooms, two maids, and a cook. According to Senate investigations, it appeared that the men did not pay Crum for lodging. In a letter to Mel Peterson, vice president of Jim Beam, Crum wrote that he and the men were "getting along like peas in a pod" and

27 "Fraud and Corruption in Management of Military Club Systems: Illegal Currency Manipulations Affecting South Vietnam." Report of the Committee on Government Operations, United States Senate, Permanent Subcommittee on Investigations (Washington, DC: U.S. Government Printing Office, I97I), pp. 9-I I, I3, 93.

${ }^{28}$ Ibid., p. 97. 
that he "showed them the brand new house I am decorating for them and they are absolutely delighted." The men lived together and partied together, with Crum sparing no expense to "cultivate the good will of PX personnel in Saigon." He entertained "lavishly" and always provided "good food, plenty of liquor, and female companionship." 29 Theirs was a bachelor pad for grown men living in a city known for its "outlaw spirit" and "all-or-nothing mentality." 30

Based in Saigon, Denby Fawcett, twenty-four-year-old reporter for the Honolulu Advertiser, lived in a small apartment above a souvenir shop. In the bedroom, a ceiling fan hung above a king sized bed to stir a breeze in the thick Saigon heat. A balcony looked out over the busy bar and entertainment district on Tu Do Street, where Americans threw back whiskey and beer, ate continental cuisine prepared by Chinese chefs, and played in nightclubs that beckoned them with neon signs and, often, Vietnamese women. In English, "tu do" translates to "freedom." Fawcett hung out at the French café Brodard's, where she listened to "California Dreamin" and other American tunes on the jukebox. At night, she dined on pepper steak and fresh vegetables shipped in from the resort city of Da Lat and prepared by a French-trained cook at a restaurant called Aterbea. Sometimes she went to Caruso's, which featured candlelight dinners, French and Italian cuisine, and imported French wine. After a meal, she liked to join friends at Jo Marcel's, a nightclub where rich Vietnamese young women danced in miniskirts and drank Coca-Cola. When columnist Ann Landers came to Vietnam to visit wounded soldiers, she invited Fawcett to have dinner with her at the posh Caravelle Hotel's rooftop restaurant. They ate frogs' legs, rice, and chocolate éclairs, and they sipped espresso high above Saigon, far from the war waging in the distance. ${ }^{3 \mathrm{I}}$

Americans in Vietnam enjoyed a variety of leisure activities. When a day's work was done, there was time for golf in Saigon, according to Ann Morrisy Merick, a white American journalist with ABC news stationed in Vietnam in 1967. The Golf Club of Saigon, near Tan Son Nhut Airport, offered eighteen holes on a relatively flat, easy course. The most challenging parts of the course weren't sand traps or lagoons, but rather the occasional outpost where ARVN soldiers stood on guard, watching for VC infiltrators. Barbed wire, land mines, and armed guards protected the

29 Ibid., pp. 104, 98, 102.

30 Tad Bartimus, War Torn: Stories of War from the Women Reporters Who Covered Vietnam (New York: Random House, 2002), pp. 253-254.

${ }^{\text {I }}$ Bartimus, War Torn, pp. 6, 22-24. 
outposts, so landing a golf ball near one was akin to landing a ball in a pond. The caddies were "sturdy Vietnamese women not much bigger than the bags they carried," Merick observed.

For those who did not care to play golf, there was the Cercle Sportif, a sprawling athletic club in downtown Saigon left behind by the French. Restless diplomats and tired embassy employees could pick up a tennis match or relax by the pool with a gin and tonic. Adventuresome Americans and wealthy Vietnamese went waterskiing on the Saigon River, skimming past US Navy river boat patrols. ${ }^{32}$ On weekends, some Americans hopped a plane or helicopter and retreated to Nha Trang, a coastal village turned resort town where lobster dinners, coconut trees, and glassbottom boats awaited them. ${ }^{33}$ Evenings meant cocktails and dinner parties. Merick noted that US Ambassador Ellsworth Bunker threw some of the best parties, featuring brandy, cigars, and imported Russian vodka. His soirees were for the "A-list" of Saigon, but for those without an invitation, there usually was a party going on somewhere, in the apartment of an American embassy worker or perhaps at the Rex Hotel. "It was a welcome break from being in the field, and we all got gussied up and partied," Merick said. ${ }^{34}$

Leisure activities, hotels, and imported goods were available for the foreigners occupying Saigon during the war. Vietnamese workers provided much of the labor that built the society in which Americans lived, worked, and played. Merick hired a French-trained Vietnamese cook and knew that "many correspondents had a houseboy or a woman who cooked for them. We all had seamstresses and tailors who could create a dressy outfit from the elegant silks and cottons that were available from our R\&R shopping trips to Hong Kong and Bangkok." ${ }^{35}$ A brochure for civilian employees of the US Air Force boasted that "one of the many pleasant aspects of duty in the Republic of Vietnam is the fact that one can afford servants." It listed the average costs per month in US dollars for hired help - cooks charged about $\$ 40-80$, while maid service ran $\$ 35$ to $\$ 60 .{ }^{36}$ Vietnamese workers made clothes, kept house, and provided entertainment for Americans in Saigon.

32 Ibid., pp. I 1 8, I33.

33 "Nha Trang," Life in Vietnam, No. I43, Dec. I6, 1967, 39, Glenn Helm Collection, Vietnam Archive, Texas Tech University, Lubbock, TX.

34 Bartimus, War Torn, p. II7. 35 Ibid.

${ }^{6}$ Pacific Air Forces Pamphlet, U.S. Air Force Civilian Employment, Republic of Vietnam, Area Information Pamphlet, Nov. 3, 1969, Sally Vineyard Collection, University of Denver Penrose Library, Special Collections, Denver, CO. 
Ads in the English-language magazine Life in Vietnam, a publication distributed to US military installations in Vietnam and Vietnamese embassies throughout the world, showcased Saigon's amenities and painted a picture of what Saigon looked like during the US occupation of Vietnam. By the mid-r96os, the Saigon skyline was made of seven- and eight-story hotels that lifted guests high above the city and offered them panoramic views so that they could gaze down at the life below. The Mai Loan Hotel featured air-conditioned rooms with balconies, a snack bar with a panoramic view of Saigon, and a restaurant offering Chinese and American foods. While the Majestic Hotel also provided air-conditioned rooms and panoramic views, it also boasted "refined French cuisine" and the "attractive and talented Ngoc Nhi" performing every night in the bar on the fifth floor. Not to be outdone, the Manhattan Hotel and Restaurant stood in "the heart of Saigon's shopping area" and presented guests with a penthouse seventh floor restaurant and "delicious French and Chinese dishes by an excellent cook from Hong Kong." After settling into their accommodations, visitors might have strolled down one of the city's commercial boulevards to find a tailor and ensure they had proper party attire. The tailor shops Waloc and Ashoka both offered ready-towear and custom-made men's and women's clothing, and ads for the shops featured a drawing of a white man in a business suit. One stop at Beautex, and a visitor could walk out with the latest French hairdo courtesy of a Paris-certified stylist. ${ }^{37}$

Not all of Saigon's amenities developed as a result of the arrival of Americans. Some hotels, restaurants, and shops dated back to the days of French colonialism. But it is important to consider the colonial character of Saigon in the context of the American war in Vietnam because some US policymakers feared American involvement in Vietnam would appear colonial. In 1964, as the Johnson administration discussed sending more personnel to Vietnam, Ambassador Henry Cabot Lodge expressed concern that more Americans - particularly civilians - in Vietnam would give a "colonial coloration" to the US presence there. ${ }^{38}$ Discussions about sending combat troops to Vietnam included fears that the conflict would look like "a white man's war against the brown." ${ }^{39}$ And on the first day of

37 Life in Vietnam, various issues, Glenn Helm Collection.

${ }^{8}$ Draft Memorandum by the Secretary of State's Special Assistant for Vietnam (Sullivan), Washington, June I3, I964, FRUS, I964-1968, I:503.

39 Telegram from the Embassy in Vietnam to the Department of State, Saigon, Jan. 6, I965, FRUS, I964-I968, 2:26. 
1967, Maxwell Taylor wondered what the United States should do about the "growing 'colonialist' image of the white man." 40 Throughout the course of the relationship between the United States and Vietnam, some American government officials worried that the United States would appear to have imperial aspirations for Vietnam, but all the while, American women and men lived in a world in Saigon marked by a colonial character. Vietnamese workers labored in a service industry aimed at providing for the needs of Americans, many of whom were in Vietnam to aid the US effort to prevent communist rule from taking South Vietnam.

Viewed from the lives of its Vietnamese residents, Saigon revealed South Vietnam's class differences and some of the consequences of the war. Wealthy and middle-class Vietnamese lived, worked, and played alongside their American occupiers. Well-to-do families owned Frenchstyle villas with comforts such as electricity, running water, Western plumbing, and separate living quarters for domestic help. ${ }^{4 \mathrm{I}}$ They lived on tree-lined boulevards and spent hot, humid afternoons playing tennis or lounging by the pool at the Cercle Sportif country club. These were the generals and government employees and their families, and they moved in the same circles as US Embassy employees, independent contractors, and military personnel stationed in the city. ${ }^{42}$ Journalists and newspaper editors tried to inform readers about their government's activities, even as authorities periodically shut down newspapers and arrested reporters who criticized the government. As of fall 1967, twenty-seven daily newspapers circulated throughout Saigon, each with a few thousand subscribers. ${ }^{43}$

Young Vietnamese frequented coffee shops on Tu Do Street, which ran from Notre Dame Cathedral near the Presidential Palace to the Saigon River. Young men brought their sweethearts, and groups of friends packed tables and drank coffee, smoked cigarettes, and listened to music. French artists remained popular into the American era, but Vietnamese musicians such as Trinh Cong Son became increasingly popular with the young coffeehouse set as the war dragged on. Son's songs and other popular

40 Paper Prepared by the President's Special Consultant (Taylor), Washington, Jan. I, I967, FRUS, I964-1968, 5:2.

${ }^{4}$ Duong Van Mai Elliott, The Sacred Willow: Four Generations in the Life of a Vietnamese Family (New York: Oxford University Press, 1999), p. 255.

${ }^{42}$ Bernard Weintraub, "Footnotes on the Vietnam Dispatches," New York Times, Oct. 20, I968.

43 Howard Moffett, "Reporting the Cool-Medium War," Yale Alumni Magazine, Oct. 1967, p. 29. 
Vietnamese music of the day expressed a deep, if apolitical, longing for peace. Ballads told stories of young servicemen who missed their girlfriends and dreamed of being back in Saigon, at one of those cafes on Tu Do Street. Vietnamese employees of the US Embassy and American companies gathered at restaurants and bars and tried to make sense of America's intentions. Some gazed out over their coffee cups to the street outside, wondering what would happen to them if the Communists won. They worked for the enemy; would they be hung as traitors? The war had made life difficult, but the terms of peace that might come in the wake of an American departure terrified some Saigon residents. One American adviser remarked that a "peace scare" had begun to wash across the city as Americans made serious moves toward peace talks in $1968 .{ }^{44}$

For the poor - including the refugees the war drove from the countryside into the cities - Saigon was a constant reminder of their poverty and dislocation. By 1969, Saigon's population had increased from about 400,000 at the start of World War II to more than 2.5 million. ${ }^{45}$ Before I964, 80 percent of Vietnamese were rural farmers. By I970, 40-50 percent of the population of South Vietnam lived in a city. Many were refugees, and they hoped to make some money off the wartime economy. The population surge took its toll on the city. Traffic jammed Saigon's streets, and sewage, garbage removal, telephone, and electrical systems struggled to keep up. While Saigon's wealthy families lived in "spacious villas solidly built of stone or brick and equipped with running water, electricity, and sanitary facilities," slums literally were built out of consumerism. ${ }^{46}$ Sheets of rolled beer cans were reused as siding for homes. Aluminum shacks doubled as billboards for Miller High Life, Pabst Blue Ribbon, and Budweiser. Karen Offut, a stenographer in the Women's Army Corps who was stationed in Saigon for part of her tour of duty, noted that in Saigon, "there were just thousands and thousands of people and then there would be big mansions and right next to it would be these little three-sided houses or makeshift homes made out of flattened beer cans." ${ }^{47}$ In 1970, about I 58,000 Vietnamese worked for the US military

${ }^{44}$ Bernard Weintraub, "Saigon Mood Uneasy and Bitter in Face of Peace Moves by the U.S.,” New York Times, April 6, I968.

45 Army Civilian Employment: Living and Working in Vietnam (Washington, DC: U.S. Government Printing Office, 1969), p. 6.

${ }_{46}$ Area Handbook for South Vietnam, I2 I-I 24.

47 Ron Steinman, Women in Vietnam: The Oral History (New York: TV Books, 2000), p. 263; see also Area Handbook for South Vietnam, I36-I37. 
and civilian companies, while many others found income in war-related services from housekeeping to brothels. ${ }^{48}$

It was in this context that NLF terrorism played out in Saigon. While generals and politicians fought in the houses of government, and citizens demanded freedoms in the streets, foreigners living in the city provided targets and justifications for the NLF strategy of terror. Americans made use of the colonial economy their French predecessors had cultivated, presenting the appearance of yet another form of Western imperialism. The cafes and theaters they frequented offered convenient targets for bombings because they allowed the NLF to strike the city without necessarily targeting Vietnamese civilians. Vietnamese casualties always lay among the wreckage, and in cases like the My Canh restaurant bombing, sometimes were the majority of those killed, but the Western presence in Saigon bolstered the notion that the primary conflict in Vietnam was between Americans and the Vietnamese.

\section{URBAN TERRORISM}

Terrorism was a central component of NLF strategy. Douglas Pike made this argument in his studies of the National Liberation Front, which were grounded in more than a decade living in South Vietnam as an employee of the US Information Agency. Pike, a World War II veteran of the Pacific Theater, documented NLF uses of terrorism, including the massacre of several thousand civilians at Hue during the Tet Offensive. The seeming randomness of a car bomb here and an explosion in a market there belied the calculated, rational nature of the NLF's terrorism as a primary tactic in its war strategy. ${ }^{49}$ In I959, leaders in Hanoi decided that it was time to focus on "liberating the South ... to struggle heroically and perseveringly to smash the Southern regime." 50

NLF sources justified the use of terrorism as being the only choice they had given the "warlike and terrorist policies of the enemy." ${ }^{51}$ Ngo Dinh Diem, enabled by his American advisers, had unleashed a brutal secret police force on his citizens out of fear of popular political revolt against his regime, and NLF leadership, in its determination to bolster the

48 “The Urban Trend," Time, Aug. 30, I970, www.time.com/time/magazine/article/ 0,9171, 876792,00.html.

49 United States Mission in Vietnam, "Viet Cong Use of Terror: A Study," March 1967, p. 3 .

50 Ibid. $\quad{ }^{51}$ Ibid., p. 5 . 
political struggle, argued that there was no other way to fight the enemy that stood in the way of Vietnam's destiny. Not all cadres agreed with the official policy; some believed that the political struggle alone could topple the Saigon government, and terrorism might actually have an opposite effect than what NLF authorities intended. An indoctrination pamphlet explained that violence was an essential ingredient in the recipe of revolution: " $(\mathrm{T})$ he only correct way to organize revolutionary forces and make preparations in all areas to smash the enemy's machinery of violence is to use the appropriate form of armed struggle ... Emergence of this new struggle form not only meets an urgent demand, but is an inevitable result of the revolutionary movement. It does not contradict the political struggle, but supplements it and paves the way for the political struggle to develop." ${ }^{2}$ Confidence in the preordained nature of Vietnam's communist revolution allowed the NLF to justify its commitment to violent struggle.

NLF leaders clearly believed their movement had the moral authority in Vietnam, as the statement that in order for the NLF's political struggle to take place, terrorism was necessary proved. The notion of having the right to Vietnam's future was a central part of the broader conflict that involved the governments in Saigon and Hanoi, the NLF, and Vietnamese and foreign citizens across the political spectrum. Historian Nu-Anh Tran has the concept of "contested nationalism," in which the DRV and the RVN offered competing expressions of Vietnamese nationalism as each side argued that it had authentic claim to Vietnamese heritage and nationhood. ${ }^{53}$ Tran proposed the notion of contested nationalism in response to a pervasive bias in the historiography of Vietnamese nationalism and the Vietnam War that has cast the DRV as the rightful descendant of Vietnam's history. As Tran notes, scholars since the I970s have assumed that "only one of the two Vietnams could be authentically nationalist and, by extension, politically legitimate." ${ }^{54}$ What this approach is ultimately about, Tran argues, is not Vietnam, but US foreign policy. Historians' efforts to cast the DRV as the legitimate Vietnam have done so in order to critique US policies toward Vietnam and America's Cold War foreign

52 "Viet Cong Use of Terror," p. 6.

53 Nu-Anh Tran, "Contested Nationalism: Ethnic Identity and State Power in the Republic of Vietnam, I954-1963," ISSI Fellows Working Papers, Institute for the Study of Societal Issues, UC Berkeley, Jan. 3, 20I 2, p. 9.

54 Tran, Contentested Nationalism, p. 5. 
policies more broadly. ${ }^{55}$ The result is that writers have obscured the complexities of South Vietnam's political and social scenes.

Terrorism was central to the NLF's efforts to destabilize Saigon, and it compounded the chaos in the capital city and other urban areas where students, intellectuals, and journalists protested the government's slow movement in enacting democratic political institutions and allowing citizens to elect a civilian government. This was part of the reason why the NLF's urban terrorism strategy succeeded: Saigon already was chaotic, and the addition of terrorism influenced the government to crack down on free speech and assembly, two hallmarks of a democratic society. The stifling of civil liberties in turn validated claims by the NLF and other antigovernment groups that Saigon leadership was authoritarian. On January 4 and 5, I965, anywhere from three hundred to five hundred activists, including students, journalists, and Buddhists, marched in Saigon to protest the government, and authorities decided they must be proactive in preventing unrest. It would have to involve infiltration; the only way to stop conspiracies was to know who was leading them and what the plans were before they were put into action. ${ }^{56}$

NLF terrorists operating within three-person cells carried about assassinations, planted explosives, and launched grenades into crowded spaces. Skilled technicians from the provincial and zone headquarters built and detonated explosives and provided leadership to the cells. ${ }^{57}$ The mythology surrounding the image of the NLF as an organic movement belied the planning, training, and expertise that shaped and executed the NLF's terror strategy. The NLF's policy of terrorism was intentional, and key evidence of that is that the NLF generally used terrorism "judiciously, selectively, and sparingly." ${ }^{8}$ Cadres knew they walked a thin line between engendering fear in civilians and provoking hate. NLF leaders also worked to make it look as though terrorist activity was not connected to the NLF's political struggle. Authorities established "[c]landestine organizations for sabotage in urban areas" so that appear to have "no connection with political organizations." 59 NLF leaders knew their movement could lose credibility if its commitment to violent revolution became clear.

55 Ibid.

${ }^{6}$ Viet Nam Cong Hoa, Thu Tuong Phu, Vo Phong Bien Ban Buoi, Hop Ngay 6/I/65. Ho so so I 5333: Ve tinh hinh an ninh tai Sai Gon Gia Dinh nam I965. TTLTQG II.

57 “Viet Cong Use of Terror," p. 9. $\quad 5^{8}$ Ibid., p. $55 . \quad 59$ Ibid., p. 8. 
The NLF aimed its terror strategy at achieving five goals, four of which were psychological. Successful terrorist attacks had the power to boost guerrilla morale and unit cohesion while at the same time destroying community structure and security. The latter made villagers feel that their government, from local chiefs to the Saigon regime, was unable to protect them. It also motivated the government to retaliate, another goal of the NLF's terror strategy. As a US study of NLF terrorism stated, "if the terrorist is effective and if the government sees itself in a crisis, it will almost inevitably use extra-ordinary repressive measures." ${ }^{60}$ Terrorism also served as advertising and earned the NLF an international reputation. It was not always favorable publicity, though. In January I966, Yugoslavia, the United Arab Emirates, and Algeria issued a joint statement urging the Hanoi government and the NLF to do away with their terror policy, as it harmed the reputation of the Vietnamese communist movement among their citizens. Finally, the NLF had a quantifiable goal, which was to "eliminate the entire leader class of Vietnamese villagers." ${ }^{1}$ Assassinating village chiefs and rising leaders removed the greater threat to the NLF than high political authorities in Saigon because the countryside was where the NLF worked to establish control.

NLF terrorism targeted and disrupted rural and urban life. South Vietnamese and US government and military sources, news coverage, and International Control Commission reports documented the violence, although because the attacks tended to yield small numbers of casualties at a time, reports failed to garner much attention. This served the NLF well, as it ensured that the brutality of the organizations strategy was not central to the NLF's international image. The Front mainly targeted villages, especially hamlets it considered to be pro-Saigon, and the goal of an attack was typically to cause confusion and fear rather than to kill a large number of civilians. One of the methods for achieving this goal worked this way: Guerrillas approached a village and fired a few rifle shots. Self-defense forces and government security troops stationed there then had to decide whether it was an actual attack or simply harassment. If the commanding officer decided it was an attack that required a military response, troop attention would be diverted from another area, where the guerrillas would then stage an actual attack. If the commanding officer chose to not respond, believing the shots to be harassment, the lack of response would leave villagers worried that government troops were not

${ }^{60}$ Ibid., p. 52. ${ }^{6 \text { I }}$ Ibid. 
committed to protecting them. It bred insecurity within the village, the ultimate goal of the small-scale terrorism, as bullets punctured daily life, if not human bodies. ${ }^{62}$ When targeting individuals in rural areas, guerrillas focused on village and hamlet chiefs, government employees, teachers, and suspected "informants" and other "traitors," as well as foreigners including priests and other missionaries, humanitarian aid workers, and US government employees. ${ }^{63}$

Psychological destabilization was also the goal of terrorism in Saigon, and grenades and other explosives were the primary weapons. One report referred to a bicycle, its hollow frame packed with explosives, as an "instrument of death." ${ }^{64}$ It was an apt description of the bicycle that caused the secondary explosion at the My Canh restaurant. Urban terrorism aimed to harm Americans and the Vietnamese who worked with them. On Christmas Eve 1964, NLF guerrillas drove a car loaded with explosives into a parking lot behind the Brinks Hotel Bachelor Officers Quarters in Saigon. When it detonated, the blast killed two US servicemen and wounded more than sixty American military personnel and Vietnamese civilians. Three months later, NLF terrorists again used an explosivesladen vehicle to bomb the US Embassy in Saigon, killing twenty and wounding more than one hundred eighty people.

The NLF bombing of the Kinh-Do Theater in February 1964 became a training case study for the Front and particularly rattled Americans living in Saigon. Located near the Presidential Palace in the busy center of the city, the Kinh-Do Theater served Americans, including dependents of US military and government personnel. The area surrounding the theater included a US dispensary, US Special Forces headquarters, and the homes of South Vietnamese civil servants and "the city bourgeois." A captured NLF document noted, in translation, that "attacking it will create a strong impression at home and abroad and will greatly affect the morale of Americans, both in Vietnam and in the United States." ${ }^{65}$ A few minutes before the eight o'clock movie started on the evening of February I6, a team of three guerrillas arrived at the theater in a car. The first man to jump out was the leader: a sharpshooter and a judo expert who had combat experience. The other two guerrillas lacked the experience and skill of the leader, but they had proven their loyalty to the NLF cause. Once out of the car, the marksman pulled out a gun and shot a security guard while yelling to Vietnamese police officers near the theater, "We

${ }^{62}$ Ibid., p. $39 . \quad{ }^{63}$ Ibid., pp. I6-38. ${ }^{64}$ Ibid., p. $40 . \quad{ }^{65}$ Ibid., pp. 63-64. 
attack the Americans. Run away brother policemen and agents." ${ }^{66}$ Panicked moviegoers rushed from the lobby into the seating area as the other guerrillas lobbed grenades into the theater. Three American servicemen were killed and thirty-two patrons were injured in the blast, including three American women, two American children, and one British civilian. ${ }^{67}$

Urban terrorism, like its rural variety, also targeted Vietnamese who held esteemed positions in the community and were leaders or had leadership potential. The assassination of Tu Chung, editor of the newspaper Chinh Luan (Political Discussion), on December 30, 1965, was an example of that goal. Chinh Luan leaned anti-communist, but it also criticized the Saigon government and US intervention. Chung and editor in chief Dang Van Sung received death threats at the newsroom, and when a letter arrived in mid-December announcing a "last warning," the editors published it, along with a reply stating that the paper was committed to balanced news coverage and would critique groups, individuals, governments, and nations that deserved criticism. This stand cost $\mathrm{Tu}$ Chung his life. As he stepped out of his car in front of his home, NLF guerrillas shot him four times, killing him, before fleeing the scene on a motorbike. ${ }^{68}$

Although the image of the black pajama-clad guerrilla seems most well placed in a rural setting, the city by its nature was perhaps an easier target for NLF terrorism and infiltration. More than two million people lived in Saigon, and the population swelled as war refugees fled the fighting in the countryside. Even despite security checkpoints on the outskirts of the city, ID checks, and house-to-house inspections throughout town, Saigon offered anonymity to NLF guerrillas who organized terror cells, infiltrated political activist groups, and smuggled drugs and supplies out of the city. Prime Minister Nguyen Cao Ky emphasized development as the key to defeating the NLF, authorizing the building of a housing project for the urban poor. Youth volunteer groups ministered to Saigon's needy and worked in community organizing, but NLF worked through the wellconnected elites as much as it did the disaffected poor. ${ }^{69}$

Attacks on Saigon had continued through 1964 as did discussions of what to do with American dependents. Due to NLF infiltration of political

${ }^{66}$ Ibid., p. $77 . \quad{ }^{67}$ Ibid., p. 79.

${ }^{68}$ Ibid. pp. 47-49. For an in-depth analysis of Chinh Luan, see Nu-Anh Tran, "South Vietnamese Identity, American Intervention, and the Newspaper Chinh Luan [Political Discussion], 1965-1969," Journal of Vietnamese Studies, Vol. I, No. I-2 (Feb./ Aug. 2006), I69-209.

${ }^{69}$ Robert Shaplen, "Letter from South Vietnam," New Yorker, March I966, p. 58. 
groups and protest movements, it was not always clear to the CIA or other outsiders who exactly was behind the unrest in Saigon. In August, CIA agents uncovered orders from the NLF's Saigon/Cholon/Gia Dinh special committee instructing cadres to foment unrest among Saigon's high school and university students. Cadres were to infiltrate student and Buddhist organizations and encourage opposition to the government. ${ }^{70}$ Yet embassy and CIA reports also indicated agitation by politicians and others not affiliated with the NLF.

Late November saw a series of demonstrations in Saigon, some of which escalated to violence as citizens protested the government of Tran Van Huong. A march on November 22 grew particularly large, spiraled out of control, and resulted in violence. US Embassy officers observed demonstrators leaving the National Pagoda, and as they marched toward Gia Long Palace, a government residence, the crowd swelled to between 200 and 300 marchers. Security forces struggled to contain the protest. When city firefighters opened fire hoses on the crowd, demonstrators grabbed the hoses and turned them on the firemen. Anti-riot troops armed with nightsticks arrived, and the crowd dispersed, but later that afternoon, anti-government protesters returned to the streets with an even larger crowd. A US Embassy report estimated the number of protesters in the afternoon demonstration at 2,000, marching from the National Pagoda to Cong Ly Boulevard into the city center. Some of the protesters drove a truck with a loudspeaker in the march, calling for Huong's resignation. Security officers attempted to drown out the protesters with their own sound truck, but the vehicle stalled, and once they restarted it, it turned out that the speaker was no match for the protest's blaring loudspeaker. Violence erupted between civilians and police, grenades were thrown, and Huong eventually called in airborne troops, who arrived with tear gas and live ammunition. Nearly sixty civilians, police, and military personnel were injured, and one fifteen-year-old boy named Nguyen Van Khuong was reported dead. An embassy assessment of the demonstration suggested that opposition political figures and Buddhist leaders were involved in planning and instigating the event. ${ }^{7 \mathrm{I}}$

70 CIA Intelligence Information Cable, Viet Cong Plans to Further Anti-Government Demonstrations in the Saigon Area, Sept. 6, I964, 2I20319003, Douglas Pike Collection: Unit oI - Assessment and Strategy, Folder I9, Box 03. The Vietnam Center and Archive, Texas Tech University.

${ }^{71}$ Telegram 191 82 from AmEmbassy Saigon to SecState Washington, DC, Nov. 23, I964. Lyndon B. Johnson National Security Files: Vietnam, I963-I969, 998Microo295, The Vietnam Center and Archive, Texas Tech University. 
Students were especially angry because of Huong's orders increasing draft calls. On November 24, a group of several hundred Vietnamese students seized Le Quy Don School in Saigon and held an American woman teacher hostage in protest of the draft. It was a school that educated the children of Saigon's wealthy families. Huong retaliated by sending armed military police out into the city's streets to try and prevent subsequent demonstrations, but unrest continued. Students also occupied five other schools throughout the city, including one owned by the director of a Saigon radio station..$^{72}$ CIA agents searched for evidence of NLF involvement in the demonstrations, and although they reported nothing conclusive, embassy officers asserted that they must "assume VC hand" guided the unrest. Embassy officials asserted that the work of the "young punks" who participated in the school seizures and street protests did not represent the general will of Saigon residents. ${ }^{73}$

On February 7, I965, President Lyndon B. Johnson announced that all American dependents of US personnel in Vietnam were to be evacuated immediately from the country. The directive came in the wake of growing anti-American sentiment, violence against Americans, and sneak attacks in Saigon. Most dependents were wives and children of American diplomats and advisors, and the vast majority lived in Saigon, the heart of US operations in the early I960s. Members of the Johnson administration had been in talks about evacuating American dependents since January of I964 "in light of recent terrorism against Americans in Saigon." By February 20, 1964, Americans had reported fifteen attacks, including the bombing of a softball game in which five Americans died and more than fifty, including dependents, were wounded, in addition to the incident at the Kinh-Do Theater. ${ }^{74}$ But despite the attacks on Americans, some officials opposed the evacuation of dependents from Saigon because they feared it would cause panic among Vietnamese who might consider the evacuation a sign that the United States was preparing to abandon them. ${ }^{75}$ Others, such as General William Westmoreland, worried that

72 "Students Seize School in Saigon," New York Times, Nov. 24, I964, p. I.

73 Telegram O2I248 from AmEmbassy Saigon to SecState Washington, Nov. 25, I964. Lyndon B. Johnson National Security Files: Vietnam, I963-I969, 998Microo295, The Vietnam Center and Archive, Texas Tech University.

${ }^{74}$ Message from the Ambassador in Vietnam (Lodge) to the President, Saigon, Feb. 20, 1964, Foreign Relations of the United States, I964-I968 (Washington, DC: U.S. Government Printing Office, I992) I:94-95. [Hereafter FRUS, followed by year and volume].

75 Memorandum from the Secretary of Defense (McNamara) to the President, Washington, March I6, I964, FRUS, I964-I968, I:I 53-167. 
sending wives and children home would harm the recruiting efforts of some agencies and prevent personnel from staying in Vietnam beyond a one-year tour of duty. ${ }^{76}$ From the perspectives of some of Johnson's advisors, evacuating dependents held serious consequences for the US mission in Vietnam.

In 1966, the NLF launched an urban strategy called the "I966 Revolution." It emphasized that the political struggle in the cities was of equal value to the armed struggle in the countryside. The strategy specifically targeted urban youth to enlist them as the foot soldiers in the urban confrontation between authorities and citizens. ${ }^{77}$ NLF terrorism motivated the US government and military to relocate Americans away from Saigon. In August 1966, US President Lyndon Johnson ordered the military to reduce its presence in the city. The plan, known as "Operation MOOSE" for "Move Out of Saigon Expeditiously," relocated the majority of US Army personnel from Tan Son Nhut air base in Saigon to the base at Long Binh..$^{78}$ It also made Saigon off-limits to combat GIs on $\mathrm{R} \& \mathrm{R}$ and to all incoming troops. According to a Time magazine report, Operation MOOSE cut the number of American soldiers in Saigon from about 71,000 to about 36,000 by the end of $1967 .{ }^{79}$ In March 1972, as US troops gradually left Vietnam due to President Richard Nixon's "Vietnamization" plan, the mayor of Saigon announced that all "hostess bars" catering to Americans must move out of downtown Saigon. The mayor ordered the clubs to the city's ninth precinct, across the Saigon River. The only way to get there was by boat. ${ }^{80}$

Writing for the Yale Alumni Magazine in October 1967, Howard Moffett offered an astute observation about Americans' understanding of the Vietnam War: "There has never been a more difficult war to cover, but it is nevertheless startling to realize that Newsweek's most successful

${ }^{76}$ Summary Record of a Meeting, Honolulu, June I, I964, FRUS, I964-I968, I:422-433.

77 Quinn-Judge, Vietnam and the West, pp. I65-166.

${ }^{78}$ Memo, Department of the Army, 28 Headquarters, USA Regional Communications Group Vietnam, "Report of MOOSE Action, FY69," Oct. 3 I, I968, National Archives, Records of the United States Forces in Southeast Asia. Record Group 472, Box II6, Folder I 378 - "Project Moose Reports." See also, Memo, "United States Army, Vietnam MOOSE Plan, FY 70," April I, I969. National Archives, Records of the United States Forces in Southeast Asia. Record Group 472, Box II6, Folder I 378 - "Project Moose Reports."

79 “Cleaning Up Saigon,” Time, Dec. I, I967, www.time.com/time/magazine/article/o,9I7I, 7I 20 I I, O०.html.

80 “Closing Time," Time, March 20, I972, www.time.com/time/magazine/article/o,9I7 I, $942505,00 \cdot \mathrm{html}$. 
treatment of Vietnam came in this summer's special issue on 'The Vietnam War and American Life.' We have almost given up trying to understand what is happening over there and are now simply trying to explain what effects it has had here at home." ${ }^{8 \mathrm{I}}$ Moffett casts South Vietnam's problem as one similar to the tensions felt in Iran, Afghanistan, and other countries where an educated, worldly, urban elite clashed or was disconnected from the rural populace, which tended to be conservative in their politics and traditional in their culture. He called it "the conflict between traditionalism and modernism in a developing society." Colonialism had widened the gap by concentrating the best schools in the cities. Rural youth whose families could afford to send them to urban schools often never returned home, having fallen under the spell of the city's charm, and, on a practical level, found that the kinds of professional and civil service jobs their education prepared them for existed primarily in the cities. Educated young adults stayed in the cities rather than returning home and serving as a bridge between city and country across which they could share ideas and build a common worldview. The influx of rural refugees into cities because of the war remained isolated, and their circumstances were not conducive to establishing connections between country and city. It was unclear whether they were loyal to the government or the NLF. ${ }^{82}$

Americans involved with the US intervention in Vietnam ignored or dismissed the educated elites, conceiving of all Vietnamese as simple peasants. Americans' inability or unwillingness to acknowledge their Vietnamese friends' cultural refinement - indeed, that they were "civilized" - constituted one of the most significant missed opportunities of the Vietnam War. Educated Vietnamese resented that Americans did not treat them as equals, and this reduced the effectiveness of US intervention. ${ }^{83}$ Complicating matters further were regional divisions and resentments among the Vietnamese. Born-and-raised Southerners, who comprised the majority of South Vietnam's population, took offense to what appeared to be minority northern control in Saigon. The one million refugees who fled the north in 1954 - including Nguyen Cao Ky - seemed to dominate. Activists in Hue longed to return it to the capital of Vietnam, demoting Saigon to a second-rate city. ${ }^{84}$

South Vietnam was also split into political factions, from religious groups such as Catholics, Buddhists, the Cao Dai, and the Hoa Hao;

\footnotetext{
${ }^{81}$ Howard Moffett, "Reporting the Cool-Medium War," Yale Alumni Magazine, Oct. 1967, p. 26.

${ }^{82}$ Ibid., pp. 26-27. $\quad{ }^{83}$ Ibid., p. $27 . \quad{ }^{84}$ Ibid., p. 28.
} 
the Army; and old-line political parties such as the Dai Viets and the VNQDD. Some of these groups were even splintered within. ${ }^{85}$ The media represented the political prism that was South Vietnam. In the fall of I967, thirty newspapers were published in the country, twenty-seven of them in Saigon. Most represented a particular political point of view, and the circulation of multiple perspectives made it difficult for any one group to unify the population as the Hanoi government had united North Vietnam under one highly centralized ideology. ${ }^{86}$

Even as the American presence in Saigon dwindled, and even after the indecisive Tet Offensive of I968, the NLF understood the importance of Saigon. In I97I, NLF cadres in the Saigon area began making plans to launch a mass uprising in the capital city, believing it was key, more so than the villages, to the ultimate success of the communist movement. Saigon was a powerful cultural, political, and military symbol of South Vietnam, and with more than three million people concentrated in a fairly small area compared to two to three million rural dwellers spread throughout the Mekong Delta region, the political impact of a Saigon uprising would be greater. NLF leaders also speculated that the political engagement of Saigon's middle class would be more significant given its location in the seat of the federal government, and so convincing this group to abandon their primarily neutral stance and join the communist front would constitute a major NLF victory. ${ }^{87}$

Though confident, the cadres in and around Saigon knew that gaining the support of the urban middle class was not a foregone conclusion. Procommunist sympathies had never been the primary motivation of political unrest in the city. Opposition to the draft brought students into the streets, and austerity measures, including higher taxes, alienated small business owners and other members of the "petty bourgeoisie." 88 As frustration with President Nguyen Van Thieu spread to the political right, NLF leadership in the cities, especially Saigon, instructed cadres to try and capitalize on anti-Thieu sentiment in order to control rightist groups that would not otherwise feel any connection to the communist cause. In order to do so, the NLF would need to strengthen its leadership, build closer relationships with urban contacts, and convince the noncommunist anti-

${ }^{85}$ Ibid., p. $28 . \quad{ }^{86}$ Ibid., p. 29.

87 VC Plan for Taking Over Saigon through a Large-Scale Mass Uprising, May I8, I97I, Folder 03, Box 16, Douglas Pike Collection: Unit o2 - Military Operations, The Vietnam Center and Archive, Texas Tech University (hereafter Vietnam Archive).

${ }^{88}$ Ibid. 
Thieu element to join the NLF in demanding complete US withdrawal, not just troop withdrawal, from Vietnam. ${ }^{89}$ Capturing Saigon, NLF leaders concluded, would take a deeper political effort aimed at convincing their fellow countrymen that theirs was the right side.

There were some experienced nationalists in Saigon who would help. Educated elites like the lawyers Ngo Ba Thanh and Nguyen Long had participated in the peace movement that dated back to the Diem era. They opposed foreign support for the Saigon government and believed the NLF better represented the southern population than the US-backed Saigon government. Some joined the NLF and established anti-government organizations meant to appear independent of the Front even though their members worked secretly with the Communists. When questioned by police or Americans, the southern nationalists asserted that they were not members of Hanoi's Communist Party, called the Vietnam Workers Party or Lao Dong, which was true for many of them. For them, communism was not the point. Freedom to decide Vietnam's future was the point.

The name of the organization that Thanh and Long helped establish expressed their philosophy clearly. In 1964, they founded the Movement for the People's Self-Determination, announcing in a leaflet that the group supported "America for Americans. South Vietnam for South Vietnamese. We demand that the NLF and the government negotiate peace between the two brothers. South Vietnam must have the right to determine its own future." $9 \circ$ Members believed that if they supported the NLF, they would accumulate political capital and favor with Hanoi, which they could use if the war ended in a northern victory. Neither house arrest nor prison nor exile sapped their commitment to self-determination. They asserted their claims to nonaligned nationalism from their prison cells, during their hunger strikes, and at their press conferences. Yet what Americans and Saigon authorities saw were dangerous activists whose vision of independence would undoubtedly unify Vietnam under a communist government.

89 PRP C.C. Strategy for Political Struggle in Cities, Sept. I 5, I974, Folder 02, Box 34, Douglas Pike Collection: Unit or - Assessment and Strategy, Vietnam Archive.

${ }^{\circ}$ Truong Nhu Tang, A Viet Cong Memoir: An Inside Account of the Vietnam War and Its Aftermath (New York: Vintage Books, I986), p. 93. 